\title{
Zmienność dolnocechsztyńskiej mineralizacji kruszcowej w sąsiedztwie stref uskokowych w złożu miedziowo-srebrowym Radwanice-Gaworzyce
}

\author{
Andrzej Chmielewski ${ }^{1}$, Andrzej Głuszyński ${ }^{1}$, Sławomir Oszczepalski ${ }^{1}$, Artur Kuczak ${ }^{2}$
}

\begin{abstract}
Variability of ore mineralization in the vicinity of fault zones in the Radwanice-Gaworzyce copper-silver deposit. Prz. Geol., 67: 147-153; doi: $10.7306 / 2019.4$

A b s t r a c t. The characteristic of ore mineralization in the immediate vicinity of fault zones in the Lower Zechstein deposits is shown. All presented outcomes are on the basis of rock material taken from mining profiles in the Radwanice-Gaworzyce deposit area. During conducted studies ore minerals and oxide minerals were identified under optical microscope in reflected light and photographic documentation of the examined samples was undertaken. In addition, microprobe examination was carried out for selected samples from the studied profiles along with calculations of the chemical composition of individual ore minerals. In all analyzed profiles, Rote Fäule oxidized zone (enriched with hematite) was found, which occurs at various levels of the Kupferschiefer series and the reduced zone (enriched with ore minerals) over the oxidized series. The redox front cuts across the boundaries of lithostratigraphic units, moving from the Weisliegend to the higher parts of the Zechstein Limestone. The primary ore mineralization in the examined profiles is the chalcocite-digenite association with subordinate bornite and covelitte recorded in the reduced series. Furthermore, the secondary sulphide mineralization in the direct vicinity of tectonic deformation and faults superimposed on primary ore mineralization and hematite enrichments is observed and it is represented by chalcopyrite, bornite, tennantite, tetrahedrite and pyrite, both within reduced and oxidized zones.
\end{abstract}

Keywords: Zechstein, fault zones, ore mineralization, copper-silver deposits, Rote Fäule

Dotychczasowe prace badawcze prowadzone na monoklinie przedsudeckiej ujawniły szereg prawidłowości rozmieszczenia dolnocechsztyńskiej mineralizacji kruszcowej (np. Oszczepalski, 1999; Speczik, 1995), w tym strefowość ułożenia mineralizacji w stosunku do strefy utlenionej Rote Fäule (ryc. 1, 2) oraz obecność mineralizacji reliktowej w utworach utlenionych (np. Rydzewski, 1978; Oszczepalski, 1994, 2007; Oszczepalski, Rydzewski, 1997; Oszczepalski i in., 2002; Chmielewski, 2011, 2014, 2016; Chmielewski i in., 2015; Oszczepalski, Chmielewski, 2015). Znacznie mniej uwagi poświęcono dotychczas roli deformacji tektonicznych w procesach mineralizacyjnych (Salski, 1975, 1977; Markiewicz, 2007; Chmielewski $\mathrm{i}$ in., 2018).

Znajdujący się w kopalni O/ZG Polkowice-Sieroszowice oddział G-32 (piętro R2W) (ryc. 3), gdzie wykonano obserwacje ścian wyrobisk eksploatacyjnych i opróbowanie utworów cechsztyńskiej serii miedzionośnej, jest jednym z najdalej na zachód wysuniętych eksploatowanych fragmentów złoża Radwanice-Gaworzyce. Analizowany obszar znajduje w SW części monokliny przedsudeckiej, w odległości ok. $5 \mathrm{~km}$ na północny-wschód od dyslokacji wyznaczających strefę uskokową środkowej Odry. Usytuowanie blisko granicy bloku przedsudeckiego spowodowało, że rejon ten cechuje się występowaniem intensywnych zaburzeń tektonicznych w obrębie serii złożowej (Markiewicz, 2007). W trakcie obserwacji struktur tektonicznych w wyrobiskach górniczych w spagowej serii cechsztynu stwierdzono stromo zapadające uskoki normalne i odwrócone oraz nasunięcia i fałdy przebiegające na kierunkach NW-SE i NE-SW.

Głównym celem zrealizowanych badań i analiz petrograficznych próbek w wybranych profilach kopalnianych cechsztyńskiej serii miedzionośnej było dokonanie charakterystyki rozmieszczenia mineralizacji kruszcowej oraz prześledzenie relacji strukturalno-teksturalnych pomiędzy minerałami kruszcowymi, tlenkowymi i skałotwórczymi w sąsiedztwie stref uskokowych napotkanych wyrobiskami na analizowanym obszarze (ryc. 4).

\section{METODY BADAŃ}

Prace badawcze obejmowały badania terenowe w oddziałach eksploatacyjnych (profilowanie i opróbowanie profili kopalnianych z cechsztyńską serią miedzionośną) oraz badania mineralogiczno-petrograficznych w świetle odbitym i przechodzącym. Ponadto dokonano obserwacji wybranych próbek w mikroskopie skaningowym oraz w mikroobszarze przy użyciu mikrosondy elektronowej CAMECA SX 100. W trakcie prac terenowych pobrano próbki skalne w interwałach co 15-20 cm dla danego profilu kopalnianego z utworów tzw. cechsztyńskiej serii miedzionośnej, obejmującej: biały spagowiec (Bs), łupek miedzionośny (T1) i wapień cechsztyński (Ca1) (ryc. 1). Profilowanie tych utworów polegało na dokonaniu makroskopowego opisu profili kopalnianych, ujmującego: litologię, granice litostratygraficzne i litologiczne, miąższość wydzielonych interwałów litologicznych, barwę skały oraz obecność minerałów kruszcowych. Próbki pobierano od stropu badanego interwału do jego spagu, lecz nie zawsze było możliwe pobranie próbek z utworów białego spagowca. Wynikiem prac terenowych jest kolekcja 252 próbek z 18 profili kopalnianych, z których wykonano preparaty do badań mikroskopowych w świetle odbitym i przechodzącym. Posłużyły one do przeprowadzenia szczegółowych obserwacji pod mikroskopem i oznaczenia składu chemicznego minerałów kruszcowych.

\footnotetext{
${ }^{1}$ Państwowy Instytut Geologiczny - Państwowy Instytut Badawczy, ul. Rakowiecka 4, 00-975 Warszawa; andrzej.chmielewski@pgi.gov.pl

${ }^{2}$ KGHM Polska Miedź S.A. Zakłady Górnicze „Polkowice-Sieroszowice”, Kaźmierzów 100, 59-101 Kaźmierzów
} 


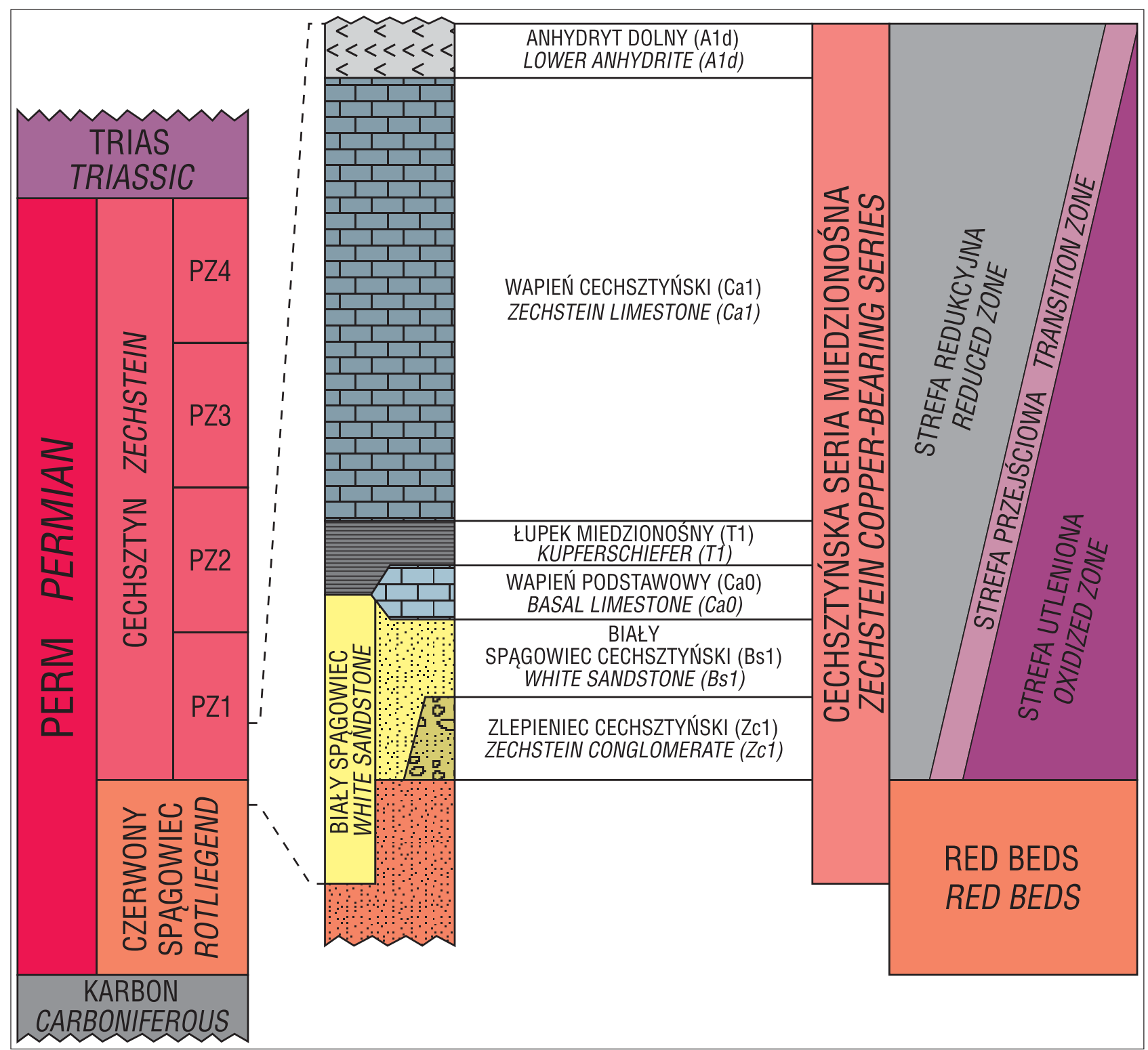

Ryc. 1. Pozycja stratygraficzna cechsztyńskiej serii miedzionośnej oraz schemat rozmieszczenia stref geochemicznych (wg Oszczepalskiego, Rydzewskigo, 1997, uzupełnione)

Fig. 1. Stratigraphic position of the Kupferschiefer series and the distribution chart of geochemical zones (after Oszczepalski, Rydzewski 1997, completed)

\section{CHARAKTERYSTYKA MINERALIZACJI KRUSZCOWEJ}

W czasie przeprowadzonych prac zbadano zarówno utwory o charakterze redukcyjnym, jak i wtórnie utlenione. W profilach kopalnianych zidentyfikowano następujące minerały kruszcowe: amalgamaty srebra $\mathrm{Ag}_{2} \mathrm{Hg}_{3}$, anilit $\mathrm{Cu}_{1,75} \mathrm{~S}$, bornit $\mathrm{Cu}_{5} \mathrm{FeS}_{4}$, chalkopiryt $\mathrm{CuFeS}_{2}$, chalkozyn $\mathrm{Cu}_{2} \mathrm{~S}$, clausthalit $\mathrm{PbSe}$, digenit $\mathrm{Cu}_{1,8} \mathrm{~S}$, djurleit $\mathrm{Cu}_{1,93-1,95} \mathrm{~S}$, elektrum (Au,Ag), galenę $\mathrm{PbS}$, geeryt $\mathrm{Cu}_{1,6} \mathrm{~S}$, gersdorfit $\mathrm{NiAsS}$, kowelin CuS, naumannit $\mathrm{Ag}_{2} \mathrm{Se}$, piryt $\mathrm{FeS}_{2}$, roxbyit $\mathrm{Cu}_{1,78} \mathrm{~S}$, sfaleryt $\mathrm{ZnS}$, spionkopit $\mathrm{Cu}_{1,4} \mathrm{~S}$, srebro rodzime $\mathrm{Ag}$, stromeyeryt $\mathrm{AgCuS}$, tennantyt $\mathrm{Cu}_{6}\left[\mathrm{Cu}_{4}(\mathrm{Fe}, \mathrm{Zn})_{2}\right] \mathrm{As}_{4} \mathrm{~S}_{13}$, tetraedryt $(\mathrm{Cu}, \mathrm{Fe})_{12} \mathrm{Sb}_{4} \mathrm{~S}_{13}$, tiemannit $\mathrm{HgSe}$, yarrowit $\mathrm{Cu}_{1,12} \mathrm{~S}$ oraz minerały tlenkowe: goethyt $\mathrm{FeO}(\mathrm{OH})$, hematyt $\mathrm{Fe}_{2} \mathrm{O}_{3}$.

Profile redukcyjne cechsztyńskiej serii miedzionośnej cechuje przewaga mineralizacji siarczków miedzi z grupy $\mathrm{Cu}-\mathrm{S}$, głównie chalkozynu z podrzędnym udziałem digenitu i bornitu. Najintensywniej okruszcowane są zazwyczaj utwory redukcyjne łupku miedzionośnego występujące ponad utlenionym stropem białego spagowca, a także redukcyjne utwory wapienia cechsztyńskiego ponad utlenionym łupkiem miedzionośnym i (lub) utlenionymi dolnymi partiami wapienia cechsztyńskiego. Tak usytuowane złoże ponad utworami utlenionymi w terminologii górniczej jest zwane „złożem zawieszonym”. Dominującą formą występowania mineralizacji kruszcowej są rozproszenia, drobne skupienia czy nagromadzenia mikrolitów i drobnych kryształów (ryc. 5A) oraz soczewki i gniazda minerałów rudnych. Poszczególne osobniki kruszców przyjmują najczęściej strukturę hipidiomorficzną, idiomorficzną i ksenomorficzną (ryc. 5B). Pospolite są drobnodyspersyjne wpryśnięcia $\mathrm{w}$ tle skalnym minerałów kruszcowych tworzących pył kruszcowy (ryc. 5C, D), zastąpienia minerałów węglanowych i detrytycznych, pseudomorfozy chalkozynowe, digenitowe, bornitowe i galenowe po framboidach pirytu, cementacje framboidów pirytowych przez chalkozyn, bornit czy galenę oraz polimineralne agregaty, składające się z bornitu, digenitu i chalkozynu. Rzadziej spotykane są żyłki kruszcowe i wypełnienia przez siarczki wolnych 


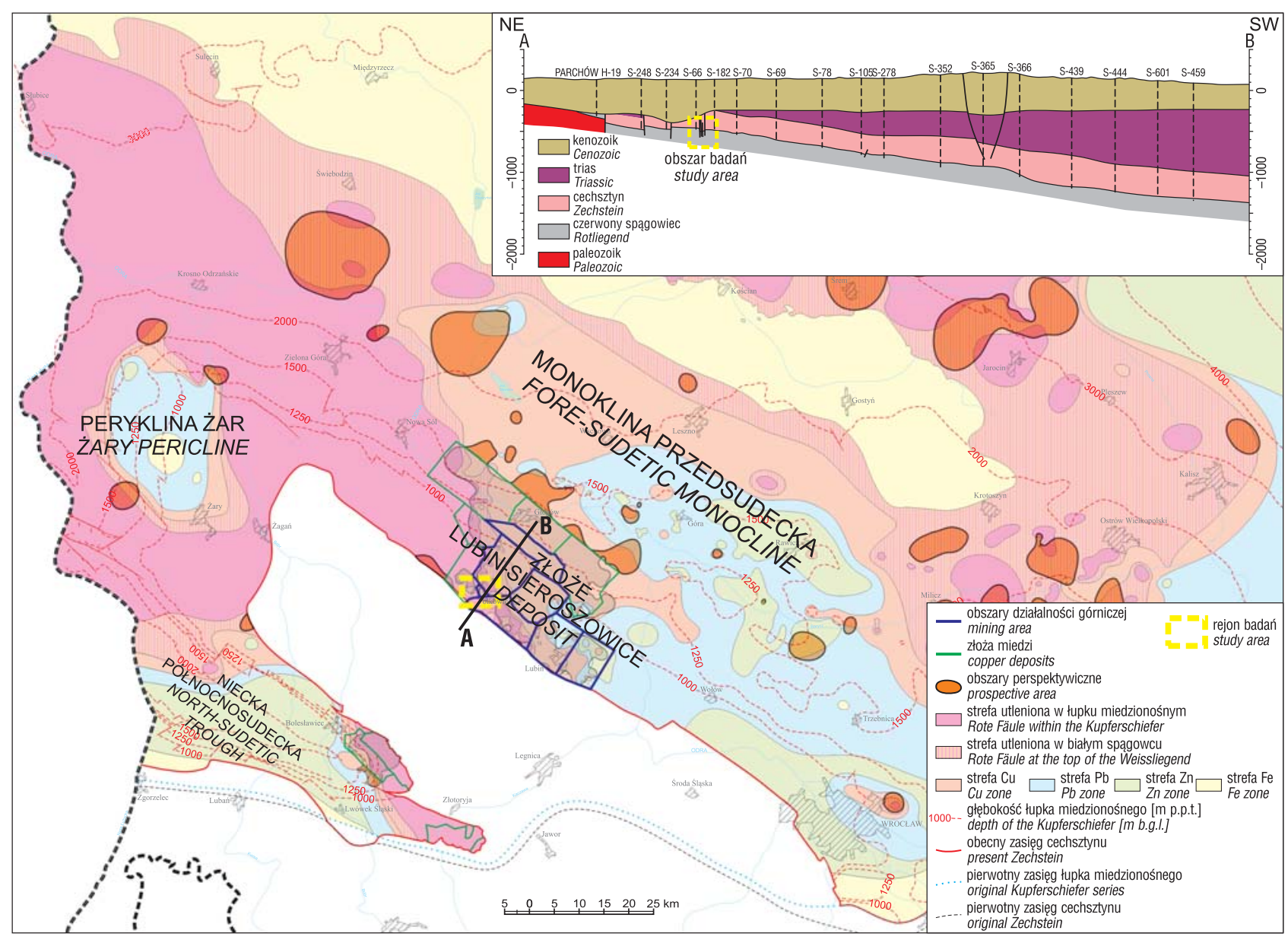

Ryc. 2. Położenie obszaru badań na tle rozmieszczenia utworów utlenionych i stref metalicznych (wg Oszczepalskiego, Chmielewskiego, 2015). A-B schematyczny przekrój przez złoże Lubin-Sieroszowice (wg Kłapcińskiego i in., 1984)

Fig. 2. Map showing location of the research area in relation to Rote Fäule areas and metal zoning patterns in the Zechstein copper-bearing series of SW Poland (after Oszczepalski, Chmielewski, 2015). A-B schematic section through the Lubin-Sieroszowice Copper District (after Kłapciński et al., 1984)

przestrzeni w skale oraz stylolitów i diaklaz. Charakterystyczne są struktury trawienia jednego z siarczków przez drugi, np. kowelinizacja bornitu. Badania w mikroobszarze wykazały podwyższone koncentracje srebra w siarczkach miedzi, m.in. w chalkozynie, digenicie i bornicie. Najwyższe koncentracje srebra stwierdzono w chalkozynie do 4\% wag., podczas gdy $\mathrm{w}$ digenicie podstawienia srebra sięgają do $0,59 \%$ wag., a w bornicie do $1,16 \%$ wag. Stwierdzono spadek koncentracji srebra w minerałach kruszcowych w kierunku stropu interwału okruszcowanego.

Profile utlenione cechuje występowanie tlenków żelaza głównie w postaci hematytu, rzadziej spotykany jest goethyt. Tlenki żelaza występują w kilku postaciach - jako pigment, grudki i agregaty mineralne, nieregularne drobne ziarna rozproszone w tle skalnym (tzw. pył hematytowy), ziemiste masy o soczewkowatych kształtach i barwach od brunatnej do czerwonej oraz w formie mikrowrostków w siarczkach miedzi. Bardzo drobne ziarna hematytu często zastępują częściowo minerały węglanowe i ziarna detrytyczne. Godne odnotowania są złożone przerosty hematytu z siarczkami miedzi (kowelinem i chalkozynem), a także wzajemne przerosty hematytu ze złotem rodzimym oraz wrostki złota w minerałach kruszcowych (ryc. 5E) na różnym poziomie w zbadanych profilach cechsztyńskiej serii miedzionośnej. Niezwykle ważne dla interpretacji pochodzenia mineralizacji kruszcowej są struktury częściowego lub całościowego zastępowania siarczków miedzi: kowelinu, digenitu, bornitu i chalkopirytu, przez tlenki i wodorotlenki żelaza (ryc. 5F). Relikty siarczków są najczęstsze w strefie przejściowej z utworów utlenionych do redukcyjnych, zwykle w najwyższych partiach interwałów utlenionych. Zastępowanie poszczególnych siarczków metali przez tlenki i wodorotlenki żelaza często przybiera charakter inwazyjny, co świadczy o procesach utleniania i degradacji kruszców.

Istotnym zjawiskiem jest obecność wtórnej mineralizacji siarczkowej, nałożonej na pierwotną mineralizację kruszcową w utworach redukcyjnych, a także na mineralizację reliktową i hematytową w utworach utlenionych (bez przejawów utlenienia). Wtórna mineralizacja kruszcowa jest ściśle związana z uskokami oraz deformacjami tektonicznymi w strefach przyuskokowych. Mineralizacja wtórna jest reprezentowana przez zespół następujących minerałów kruszcowych: chalkopiryt, bornit, tennantyt, tetraedryt oraz piryt krystaliczny. Sporadycznie notuje się obecność inkluzji selenków rtęci i srebra (tiemmanit i naumannit) w chalkopirycie. Główne formy występowania wtórnej mineralizacji kruszcowej to: wypełnienia spękań kataklastycznych ziarn pierwotnej mineralizacji kruszcowej (ryc. 5G), obwódki i impregnacje kruszcowe wokół nagromadzeń hematytu (ryc. $5 \mathrm{H}$ ), żyłki o różnokierunkowym przebiegu oraz nieregularne gniazda, soczewy, agregaty mineralne oraz mikrobrekcje. Ponadto często rejestruje się zastępowanie czy impregnacje minerałów z grupy $\mathrm{Cu}-\mathrm{S}$ przez chalkopiryt, tennantyt czy bornit. 


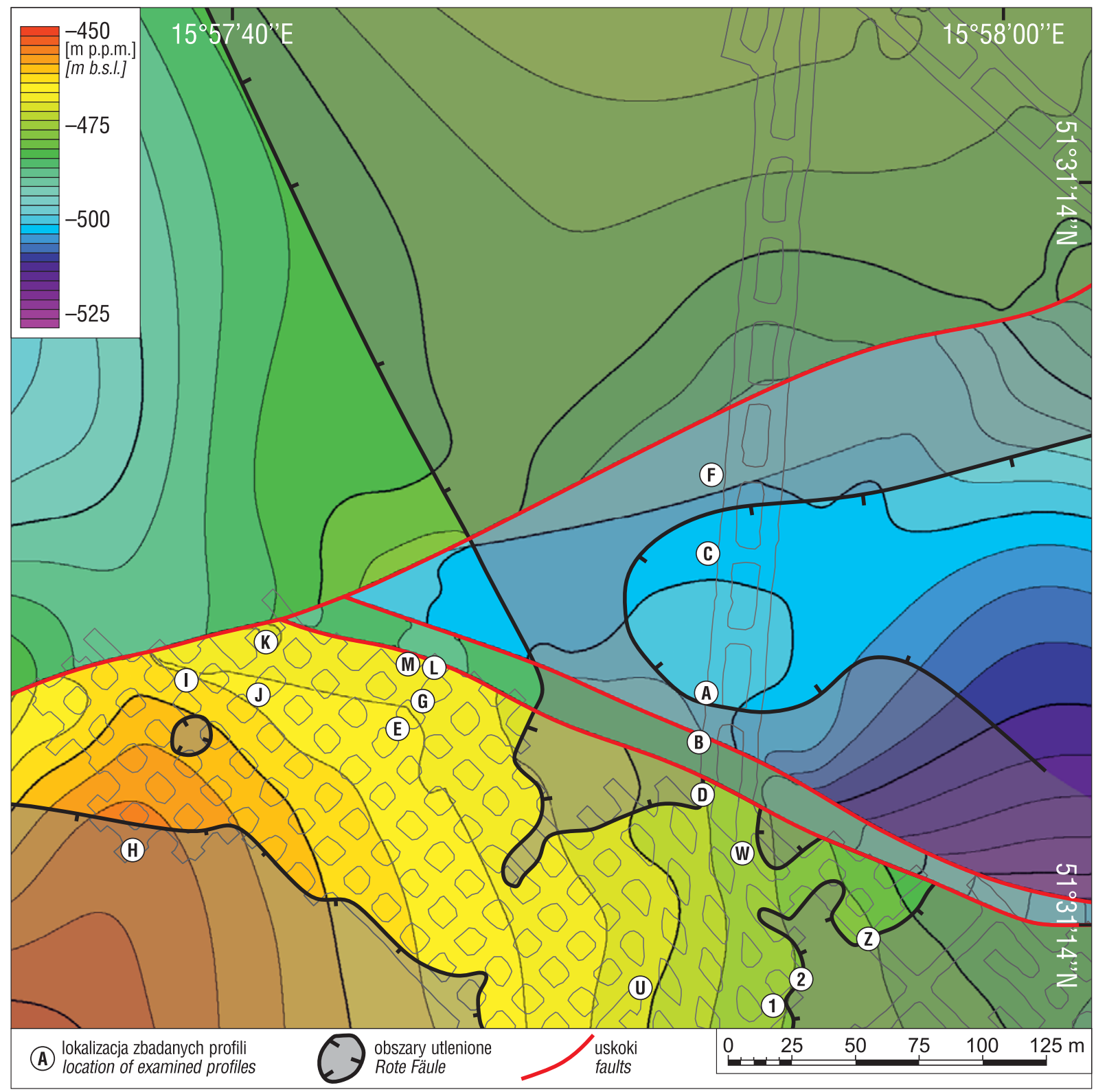

Ryc. 3. Lokalizacja zbadanych profili na obszarze złoża miedziowo-srebrowego Radwanice-Gaworzyce, na terenie kopalni Polkowice Zachodnie (oddział G-32, piętro R2W), na tle mapy głębokości p.p.m.

Fig. 3. Location of examined profiles in the Radwanice-Gaworzyce coper-silver deposit, Polkowice West mine against a depth map below the sea level

Mineralizację wtórną spotyka się najczęściej w szczelinach uskokowych, spękaniach, na powierzchniach ślizgowych oraz w zdeformowanych łupkach. Szczeliny uskokowe cechuje obecność licznych siarczków (chalkopiryt, bornit, tennantyt, tetraedryt) na ich powierzchniach i w endokontaktach w formie pokryw, nieregularnych gniazd i soczew. Często na powierzchniach spękań przyuskokowych obserwuje się ślady rekrystalizacji chalkopirytu, pirytu oraz bornitu w postaci zbrekcjowania kruszców, a także siatki wtórnych żyłek wypełnionych chalkopirytem i bornitem oraz podrzędnie tennantytem i tetraedrytem. Lokalnie w stropie piaskowców białego spagowca zaangażowanie tektoniczne jest widoczne w postaci spękań częściowo wypełnionych chalkopirytem, bornitem oraz pirytem krystalicznym. Łupek miedzionośny jest miejscami wykształcony jako łupek smolisty, bardzo silnie zdeformowany i pofałdowany, z mikrożyłkami chalkopirytu oraz bornitu.W utworach wapienia cechsztyńskiego występują często drobne szcze- liny wypełnione anhydrytem z wpryśnięciami bornitu i chalkopirytu (podrzędnie tennantytu) na ich powierzchniach szczelin. Dodatkowo obserwuje się ślady przesunięć międzyławicowych w formie powierzchni poślizgowych i brekcjowania tektonicznego, z którymi jest związana przekrystalizowana mikrobrekcja inkrustowana chalkopirytem i bornitem. Ponadto, w niektórych miejscach zanotowano tektoniczne zwiększenie miąższości złoża wskutek śródwarstwowych nasunięć w obrębie serii złożowej, które w analizowanym obszarze występuje w łupkach i wapieniu cechsztyńskim.

\section{PODSUMOWANIE}

Uzyskane wyniki badań petrograficznych prowadzą do wniosku, że zmiana składu mineralnego w pobliżu strefy redoks jest wynikiem ewolucji mineralizacji kruszcowej w utworach dolnego cechsztynu, o czym świadczą stopniowe 

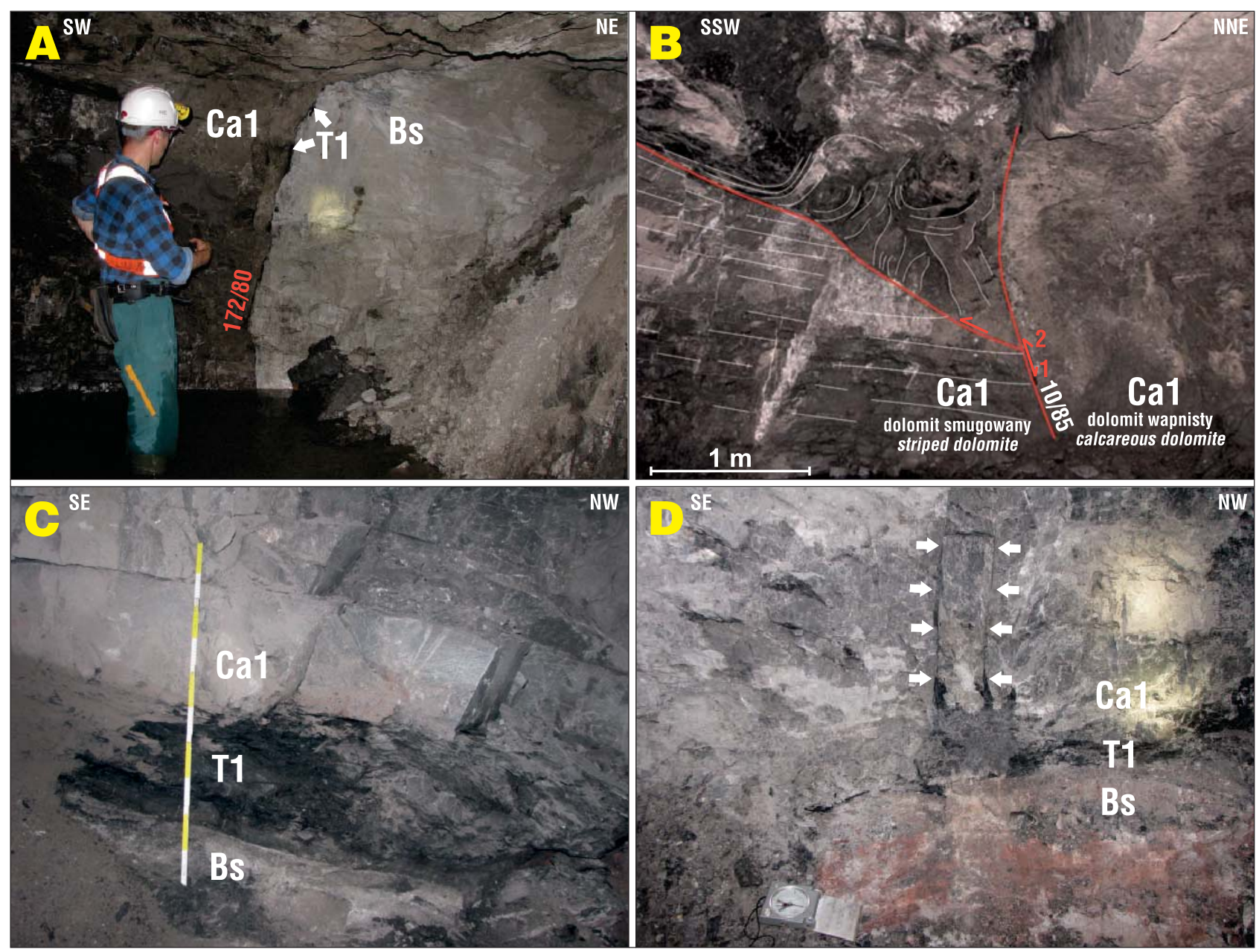

Ryc. 4. Przykłady deformacji tektonicznych obserwowanych w wyrobiskach w obrębie białego spagowca (Bs), łupku miedzionośnego (T1) i wapienia cechsztyńskiego (Ca1). A - stromy uskok zestawiający ze sobą wapień cechsztyński z piaskowcami białego spagowca. Pomiędzy węglanami i piaskowcami występuje wciśnięty tektonicznie łupek miedzionośny. B - strefa uskokowa zestawiająca ze sobą dolną cześć wapienia cechsztyńskiego (tzw. dolomit smugowany) z górną częścią węglanów Ca1 (tzw. dolomit wapnisty). Widoczne jest silne zafałdowanie warstwy węglanów przy strefie uskokowej oraz ścięcie żyły przez nasunięcie. C - tektonicznie zdeformowany (pofałdowany i zuskokowany) łupek miedzionośny. D - materiał skalny z łupku miedzionośnego wciśnięty w obręb wapienia cechsztyńskiego wzdłuż powierzchni spękań

Fig. 4. Examples of tectonic structures observed in the mine galleries in the Weissliegend sandstone (Bs), the Kupfershiefer shale (T1) and the Zechstein limestone (Ca1). A-juxtaposition of the Zechstein limestone and the Weissliegend sandstone through a fault Surface. The Kupfershiefer is squeezed along the fault plane. B - lower part of the Zechstein limestone (striped dolomite) juxtaposed with upper part of Cal carbonates (calcareous dolomite) through a fault zone. Near the fault zone the Cal carbonates are intensely folded, and the thrust cuts the vein. $\mathbf{C}$ - tectonically deformed (folded and faulted) Kupfershiefer shale. D - rock material from the Kupfershiefer shale pressed into fractures in the Zechstein limestone

przeobrażenia najwcześniej powstałych minerałów kruszcowych, aż do całkowitego ich utlenienia i degradacji bądź zastapienia przez hematyt. Składniki redukcyjnych utworów uległy zaawansowanym przemianom, prowadzącym do przekształcenia utworów redukcyjnych $\mathrm{z}$ mineralizacją kruszcową $\mathrm{w}$ utwory utlenione $\mathrm{z}$ reliktową mineralizacją siarczkową oraz hematytem. Ekspansja strefy utlenionej wyraźnie zaznaczyła się pojawieniem wtórnego czerwonego zabarwienia utworów dolnego cechsztynu oraz współwystępowaniem hematytu, a także tlenków i wodorotlenków żelaza w towarzystwie reliktowych produktów przeobrażenia i zastępowania siarczkowych minerałów kruszcowych. Występowanie mineralizacji hematytowej w wyższych partiach wapienia cechsztyńskiego niektórych profili wskazuje na najintensywniejszą aktywność roztworów hydrotermalnych $\mathrm{w}$ rejonach ich występowania. W miejscach, w których front roztworów utleniających przekroczył znacząco horyzont łupku miedzionośnego, mineralizacja kruszcowa jest uboższa w utworach węglanowych cechsz- tyńskiej serii miedzionośnej, niż w przypadku, gdy front utlenienia zatrzymał się na granicy łupku miedzionośnego z piaskowcami białego spagowca. Należy więc uznać, że obecne umiejscowienie strefy utlenionej i mineralizacji siarczkowej skupionej w ciała rudne jest efektem zachowania produktów ostatniej fazy rozprzestrzeniania się roztworów mineralizujących i ich reakcji ze składnikami osadu, przez który roztwory te przemieszczały się, i jest ono zgodne z kierunkiem rozprzestrzeniania się roztworów mineralizujących.

Mineralizacja kruszcowa strefy redukcyjnej oraz hematytowa strefy utlenionej stanowi pierwotną mineralizację względem wtórnej mineralizacji kruszcowej powstałej po uformowaniu się ciał kruszcowych i pocięciu ich przez uskoki oraz stowarzyszone z nimi deformacje tektoniczne. Obecność wtórnej mineralizacji kruszcowej na powierzchniach uskokowych w postaci bogatych koncentracji wykształconych jako zrekrystalizowane mikrobrekcje czy impregnacje oraz w najbliższym sąsiedztwie uskoków w 

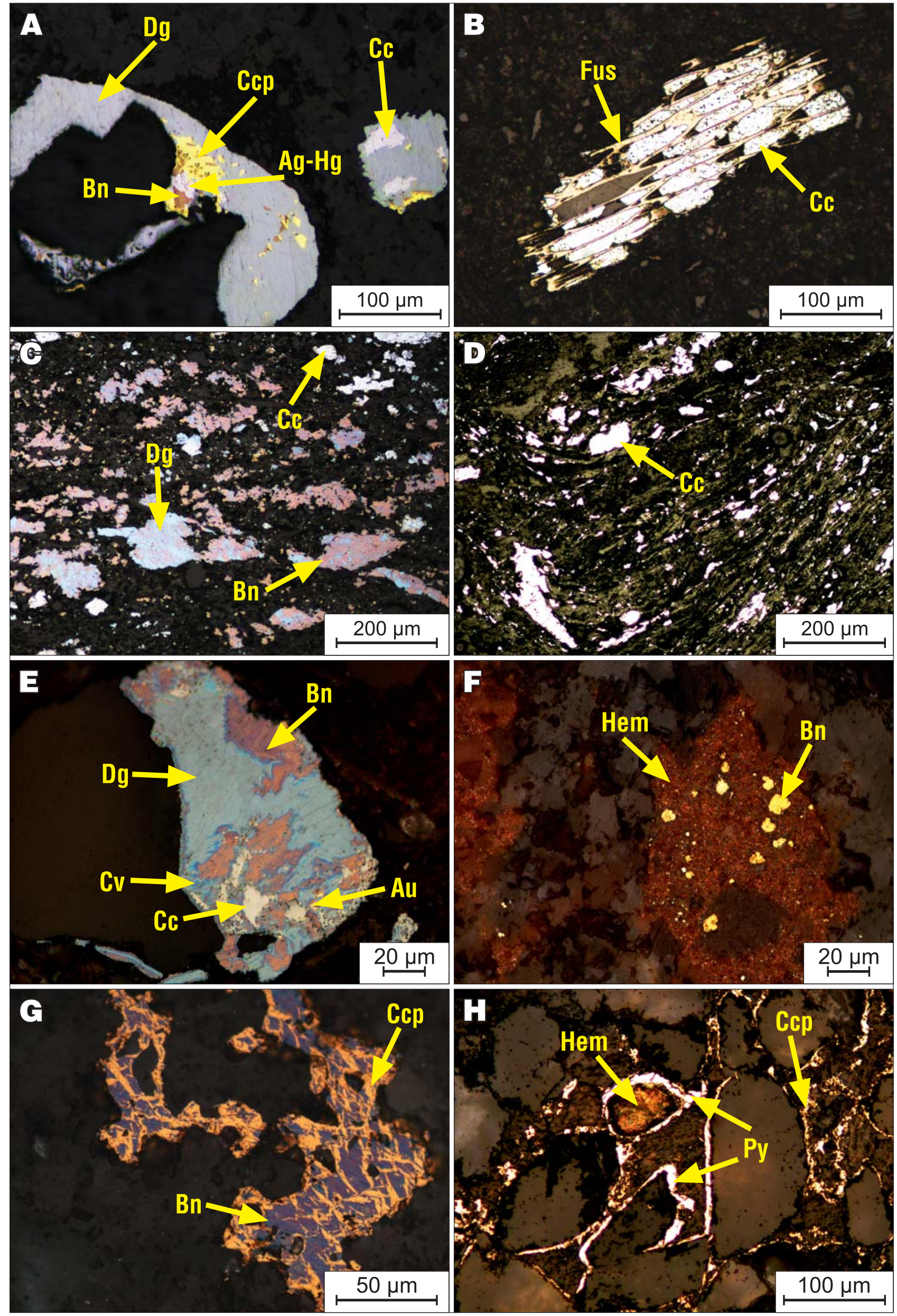
Ryc. 5. Mikrofotografie dolnocechsztyńskiej mineralizacji kruszcowej (światło odbite) (A-D - mineralizacja pierwotna; E, F - mineralizacja reliktowa; G, $\mathbf{H}$ - mineralizacja wtórna nałożona na mineralizacje pierwotną). A - digenit (Dg) z wrostkami chalkozynu (Cc), bornitu (Bn), chalkopirytu (Ccp) i amalgamatów srebra (Ag-Hg), profil U, próbka 2, wapień cechsztyński. B - wypełniania komór w fuzynicie (Fus) przez chalkozyn (Cc), profil C, próbka 3, wapień cechsztyński. C - bogata rozproszona mineralizacja bornitowo-digenitowo-chalkozynowa (Bn-Dg-Cc), profil K, próbka 11, łupek miedzionośny. D - liczny chalkozyn (Cc) rozproszony między sfałdowanymi laminami łupku oraz miejscami rozrywający laminy łupku, profil $\mathrm{H}$, próbka 3, łupek miedzionośny. $\mathbf{E}-$ agregat mineralny zbudowany z digenitu (Dg), bornitu $(\mathrm{Bn})$, chalkozynu $(\mathrm{Cc})$ i kowelinu $(\mathrm{Cv}) \mathrm{z}$ inkluzjami złota rodzimego $(\mathrm{Au}) \mathrm{w}$ utlenionym łupku, profil 1, próbka 5, łupek miedzionośny. F - relikty bornitu (Bn) w ziarnie węglanowym w towarzystwie hematytu (Hem), profil A, próbka 7, wapień cechsztyński. G - spękania kataklastyczne w bornicie (Bn) wypełniane chalkopirytem (Ccp) profil A, próbka 9, wapień cechsztyński. $\mathbf{H}$ - hematyt (Hem) z obwódką pirytu (Py) w towarzystwie chalkopirytu (Ccp), profil F, próbka 13, biały spagowiec

Fig. 5. Photomicrographs of the Lower Zechstein mineralization (reflected light) (A-D - primary mineralization; $\mathbf{E}-\mathbf{F}$ - relict mineralization; $\mathbf{G}, \mathbf{H}$ - secondary mineralization superimposed on primary mineralization) $\mathbf{A}$ - digenite $(\mathrm{Dg})$ with tiny inclusions of chalcocite $(\mathrm{Cc})$, bornite $(\mathrm{Bn})$, chalcopyrite $(\mathrm{Ccp})$ and silver amalgam $(\mathrm{Ag}-\mathrm{Hg})$, U profile, sample 2, Zechstein Limestone. B - fusinite (Fus) cells filled with chalcocite $(\mathrm{Cc})$, C profile, sample 3, Zechstein Limestone. $\mathbf{C}$-rich, disseminated bornite-digenite-chalcocite (Bn-Dg-Cc) mineralization, K profile, sample 11, Kupferschiefer. $\mathbf{D}$ - rich chalcocite mineralization $(\mathrm{Cc})$ dispersed between folded laminae, with some laminae partly broken by chalcocite crystals, H profile, sample 3, Kupferschiefer. $\mathbf{E}$ - mineral aggregate composed of digenite (Dg), bornite $(\mathrm{Bn})$, chalcocite $(\mathrm{Ccp})$ and covellite $(\mathrm{Cv})$ with native gold $(\mathrm{Au})$, profile 1 , sample 5, Kupferschiefer. $\mathbf{F}$ - relict bornite mineralization $(\mathrm{Bn})$ in the company of hematite (Hem), profile A, sample 7, Zechstein Limestone. G-Cataclastic fractures in bornite (Bn) filled with chalcopyrite (Ccp), profile A, sample 9, Zechstein Limestone. H - hematite (Hem) rimmed with pyrite (Py) and accompanied by chalcopyrite (Ccp), profile F, sample 13, Weissliegend

formie wypełnień spękań kataklastycznych ziarn pierwotnej mineralizacji kruszcowej, nieregularnych gniazd, soczew, agregatów czy żył, jest wynikiem wytrącenia minerałów kruszcowych z roztworów uruchomionych najprawdopodobniej ruchami tektonicznymi. Stwierdzone strefy uskokowe powstały w etapie ekstensyjnego rozwoju basenu permo-mezozoicznego (środkowy trias-kreda dolna?), a następnie zostały one kompresyjnie reaktywowane na przełomie kredy i trzeciorzędu (Salski, 1975, 1977; Dumicz, Don, 1977; Jowett, 1987; Markiewicz, 2007). Lokalnie doszło również do tektonicznego zwiększenia miąższości złoża w strefach występowania kompresyjnych deformacji, tj. nasunięć i zafałdowań. Ciała rudne po ich powstaniu, zaburzone tektonicznie wskutek deformacji, stały się źródłem metali dla powstania wtórnej mineralizacji kruszcowej, występującej w najbliższym sąsiedztwie stref uskokowych i deformacji ciagłych. W podsumowaniu należy stwierdzić, iż rozmieszczenie stref utlenionych determinuje położenie ciała rudnego, zarówno wertykalnie, jak lateralnie, podczas gdy powstanie deformacji tektonicznych nie miało znaczącego wpływu na wykształcenie pierwotnej mineralizacji kruszcowej, lecz spowodowało jedynie jej częściową remobilizację i wytrącenie w postaci wtórnych faz mineralnych.

Prace zrealizowano ze środków MNiSW w ramach badań statutowych PIG-PIB (temat 61.2605.1401.00.0). Autorzy dziękują KGHM P.M. S.A. za umożliwienie przeprowadzenia badań.

\section{LITERATURA}

CHMIELEWSKI A. 2011 - Zmienność mineralizacji kruszcowej w spągowych utworach cechsztynu na granicy strefy utlenionej i redukcyjnej w zachodniej części złoża Polkowice. Biul. Państw. Inst. Geol., 444: 33-45.

CHMIELEWSKI A. 2014 - Charakterystyka reliktowej mineralizacji kruszcowej w zachodniej części obszaru złożowego Radwanice (południowo-zachodnia część złoża Lubin-Sieroszowice). Biul. Państw. Inst. Geol., 458: 1-24.

CHMIELEWSKI A. 2016 - Procesy przeobrażeń dolnocechsztyńskiej mineralizacji kruszcowej w SW Polsce. Wyzwania Polskiej Geologii, III Polski Kongres Geologiczny we Wrocławiu: 13-19.
CHMIELEWSKI A., OSZCZEPALSKI S., SPECZIK S. 2015 - Relict mineralization in the transition zone, Kupferschiefer series of SW Poland. [W:] Andre-Mayer A.S. et al. (red.), Mineral resources in a sustainable world. Proceedings, 5: 1897-1900. Universite de Lorraine.

CHMIELEWSKI A., OSZCZEPALSKI S., GŁUSZYŃSKI A., KUCZAK A. 2018 - Variability of ore mineralization in the vicinity of fault zones in the Radwanice-Gaworzyce copper-silver deposit. Petrology in narrow and wide perspective: 25 years of Sessions of the Petrology Group of the Mineralogical Society of Poland. Brunów 2018. Mineral., Spec. Pap., 48: 39 DUMICZ M., DON J. 1977 - Analiza struktury monokliny przedsudeckiej w rejonie Polkowic. Acta Univer. Wratisl., Pr. Geol.-Min., 6 (378): 279-302.

JOWETT E.C. 1987 - Formation of sulphide-calcite veinlets in the Kupferschiefer $\mathrm{Cu}-\mathrm{Ag}$ deposits in Poland by natural hydrofracturing during basin subsidence. J. Geol., 95: 513-526

KŁAPCIŃSKI J., KONSTANTYNOWICZ E., SALSKI W., KIENIG E., PREIDL M., DUBIŃSKI K., DROZDOWSKI S. 1984 - Atlas obszaru miedzionośnego (monoklina przedsudecka). Wydawnictwo "Śląsk”. Katowice.

MARKIEWICZ A. 2007 - Rozpoznanie tektoniki złoża Lubin-Sieroszowice w trakcie jego zagospodarowania. Biul. Państw. Inst. Geol., 423: 151-172. OSZCZEPALSKI S. 1994 - Oxidative alteration of the Kupferschiefer in Poland: oxide-sulphide parageneses and implications for ore-forming models. Geol. Quart., 38 (4): 651-672.

OSZCZEPALSKI S. 1999 - Origin of the Kupferschiefer polymetallic mineralization in Poland. Mineral. Dep., 34: 651-672.

OSZCZEPALSKI S. 2007 - Mineralizacja Au-Pt-Pd w cechsztyńskiej serii miedzionośnej na obszarach rezerwowych górnictwa miedziowego. Biul. Państw. Inst. Geol., 423: 109-124.

OSZCZEPALSKI S., CHMIELEWSKI A. 2015 - Zasoby przewidywane surowców metalicznych Polski na mapie w skali 1:200 000 - miedź, srebro, złoto, platyna i pallad w utworach cechsztyńskiej serii miedzionośnej. Prz. Geol., 63 (9): 534-545.

OSZCZEPALSKI S., NOWAK G.J., BECHTEL A., ŽÁK K. 2002 - Evidence of oxidation of the Kupferschiefer in the Lubin- Sieroszowice deposit: implications for $\mathrm{Cu}-\mathrm{Ag}$ and $\mathrm{Au}-\mathrm{Pt}-\mathrm{Pd}$ mineralisation. Geol. Quart., 46: $1-23$.

OSZCZEPALSKI S., RYDZEWSKI A. 1997 - Atlas metalogeniczny cechsztyńskiej serii miedzionośnej w Polsce. Państwowy Instytut Geologiczny, Wydaw. Kartograficzne Polskiej Agencji Ekologicznej SA., Warszawa.

RYDZEWSKI A. 1978 - Facja utleniona cechsztyńskiego łupku miedzionośnego na obszarze monokliny przedsudeckiej. Prz. Geol., 26: $102-108$.

SALSKI W. 1975 - Tektonika okolic Lubina. Warszawa, Biul. Inst. Geol., 287: 61-198.

SALSKI W. 1977 - Rozwój tektoniczny obszaru między Lubinem a Sieroszowicami. Rocz. Pol. Tow. Geol., 47 (1): 27-48.

SPECZIK S. 1995 - The Kupferschiefer mineralization of Central Europe: New aspects and major areas of future research. Ore Geol. Rev., 9: 411-426. 